\title{
PERSEPSI SISWA TENTANG EKONOMI SYARIAH DAN HUBUNGANNYA DENGAN MINAT MEMPELAJARI EKONOMI SYARIAH
}

\author{
NONI ROZAINI \\ Dosen Universitas Negeri Medan \\ email : nonirozaini@gmail.com
}

\begin{abstract}
ABSTRAK
Permasalahan dalam penelitian ini adalah apakah terdapat hubungan antara persepsi siswa tentang ekonomi syariah dengan minat mempelajari ekonomi syariah siswa kelas XI MAN I Medan T.A 2011/2012. Penelitian ini bertujuan untuk mengetahui hubungan antara persepsi siswa tentang ekonomi syariah dengan minat mempelajari ekonomi syariah siswa kelas XI MAN I Medan T.A 2011/2012. Adapun yang menjadi sampel dalam penelitian ini berjumlah 80 siswa. Sampel diambil secara total sampling sehingga jumlah sampel sebanyak 80 siswa. Instrumen yang digunakan dalam penelitian ini adalah berupa angket.

Teknik analisis data yang digunakan adalah korelasi product moment, dan uji hipotesis dengan menggunakan uji t. Hasil perhitungan koefisien korelasi variabel $\mathrm{X}$ dan variabel $Y$ diperoleh $r_{\text {hitung }}=0.231$ sementara $r_{\text {tabel }}=0.220$ pada taraf signifikan $95 \%$ dengan $\mathrm{n}=80$. Dengan demikian hubungan persepsi siswa tentang ekonomi syariah (Variabel X) dengan minat mempelajari ekonomi syariah (Variabel Y) dikategorikan sedang. Selanjutnya dalam pengujian hipotesis dengan uji $t$ diperoleh $t$ hitung $=2.101$ sementara $\mathrm{t}_{\text {tabel }}=1.66$. Hal ini berarti $\mathrm{t}_{\text {hitung }}(2.101)>\mathrm{t}_{\text {tabel }}(1.66)$ pada taraf signifikan $95 \%$ dan $\alpha 0.05$ dengan $\mathrm{dk}=\mathrm{n}-2=80-2$. Dengan kata lain hipotesis dapat diterima. Dengan demikian dapat disimpulkan bahwa terdapat hubungan yang positif dan signifikan antara persepsi siswa tentang ekonomi syariah dengan minat mempelajari ekonomi syariah siswa kelas XI MAN 1 Medan T.A 2011/2012.
\end{abstract}

Kata kunci : Persepsi siswa tentang ekonomi syariah, minat mempelajari ekonomi syariah.

\section{A. PENDAHULUAN}

Pengaruh pendidikan terhadap pembentukan pribadi dan kualitas manusia sangat besar, sehingga tidak heran lagi hampir setiap hari manusia berusaha untuk merubah hidupnya melalui proses belajar mengajar. Proses belajar terjadi karena adanya interaksi antara peserta didik dengan lingkungannya. Oleh karena itu, lingkungan perlu diatur sedemikian rupa sehingga timbul reaksi peserta didik ke arah perubahan tingkah laku yang diinginkan.

Dalam belajar meliputi tidak hanya pada mata pelajaran, tetapi juga penguasaan, minat, persepsi, dan cita-cita. Dari beberapa faktor yang mempengaruhi kegiatan belajar, pada penelitian ini yang menjadi sorotan adalah persepsi. Dimana persepsi adalah proses menyangkut masuknya pesan atau informasi ke dalam otak manusia. Melalui persepsi manusia terus menerus mengadakan hubungan dengan lingkungannya. 
Menurut Muttaqin (2004:8), pendidikan ekonomi syari'ah di Indonesia secara formal diajarkan di sekolah, baru pertama kali muncul di Kota Tasikmalaya tahun 2002. Materi ekonomi syariah disampaikan dalam satu mata pelajaran muatan lokal di tingkat SMP/Mts dan SMA dengan durasi 2 jam pelajaran.

Saat penulis melakukan observasi di MAN I Medan, persepsi siswa terhadap ekonomi syariah berbeda-beda, ada persepsi yang positif dan persepsi yang negatif. Sebagian besar siswa berpendapat bahwa ekonomi syariah itu sama halnya dengan ekonomi konvensional. Anggapan siswa itu perlu diubah karena sistem ekonomi syariah itu berdasarkan kaidah islam, dimana siswa harus menyadari bahwa tujuan hidup adalah ibadah kepada Tuhan.

Dengan adanya persepsi siswa yang berbeda tentang ekonomi syariah dapat menimbulkan image yang negatif terhadap ekonomi syariah. Hal ini yang mendorong siswa kurang berminat untuk mempelajari ekonomi syariah, Agar image negatif siswa tentang ilmu ekonomi syariah berkurang, maka dibutuhkan ketertarikan dan rasa senang siswa dalam mempelajari ekonomi syariah. Minat belajar yang besar cenderung menghasilkan prestasi yang tinggi, sebaliknya minat belajar yang kurang akan menghasilkan prestasi yang rendah.

\section{B. KAJIAN TEORITIS}

\section{Persepsi Siswa Tentang Ekonomi Syariah}

Dalam kehidupan sehari-hari, indera penglihatan merupakan indera yang mempunyai arti penting dalam menyerap informasi-informasi yang datang dari luar, dimana informasi tersebut akan diproses menjadi suatu pengalaman yang baru. Data atau informasi tersebut diinterpretasikan sehingga menjadi suatu persepsi.

Persepsi berasal dari bahasa inggris seperti yang ditulis Echlos dan Sadly (2003:88) yaitu "Perception yang berarti penglihatan, tanggapan dan daya memahami sesuatu". Jalaluddin (1998:1) menyatakan bahwa "Persepsi adalah pengalaman tentang objek peristiwa atau hubungan-hubungan yang diperoleh dengan menyimpulkan informasi dan menafsirkan pesan”. Chaplin (2001:132) memandang persepsi sebagai proses mengetahui atau mengenali objek dan kejadian objektif dengan bantuan indera. Sejalan dengan itu Slameto (2010:102) mengutarakan bahwa "Persepsi adalah suatu proses yang menyangkut masuknya pesan atau informasi ke dalam otak manusia". Melalui persepsi, manusia secara terus menerus mengadakan hubungan dengan lingkungannya. Hal ini dilakukan dengan inderanya yaitu penglihatan, pendengaran, perabaan, perasa dan juga penciuman. Sedangkan Young (dalam Chaplin, 2001:133) bahwa "Persepsi merupakan aktivitas mengindera, mengintegrasi, dan memberi penilaian pada objek fisik maupun sosial dan penginderaan tersebut tergantung pada stimulus fisik maupun stimulus sosial yang ada di lingkungannya".

Menurut Syam (2002:3) ada beberapa indikator yang mendasari persepsi siswa tentang ekonomi syariah yaitu:

1. Memberi arti tentang ekonomi syariah

Kemampuan siswa untuk menafsirkan arti dari ekonomi syariah, kemudian siswa tersebut dapat merangkai dan memberi makna tentang ekonomi syariah. 
2. Melihat perbedaan ekonomi syariah dengan ekonomi lainnya

Siswa dapat melihat melalui indra penglihat untuk dapat membedakan ekonomi syariah dengan ekonomi lainnya.

3. Menyadari pentingnya memahami ekonomi syariah

Siswa menaruh perhatian terhadap ekonomi syariah sesuai dengan kepercayaan sikap dan menerimanya sebagai hal yang benar.

4. Menerima informasi tentang ekonomi syariah

Proses aktif dari siswa untuk menerima informasi dari berbagai media baik media cetak maupun elektronik dan menyakini betul-betul informasi tersebut dengan jelas

5. Terangsang untuk mempelajari ekonomi

Siswa bereaksi terhadap ekonomi syariah dimana reaksi ini dapat dilihat dari motivasi teman, maupun keluarga

Minat sangat erat kaitannya dengan perasaan, bila seseorang berminat akan sesuatu maka ia akan selalu berusaha dengan sungguh-sungguh dan penuh perhatian untuk mendapatkan hasil yang baik dari sesuatu yang diminatinya itu. Slameto (2010:180) menyatakan bahwa "Minat adalah suatu rasa lebih suka dan rasa keterikatan pada suatu hal atau aktivitas, tanpa ada yang menyuruh". Minat pada dasarnya adalah penerimaan akan suatu hubungan antara diri sendiri dengan sesuatu diluar diri. Semakin kuat atau dekat hubungan tersebut, semakin besar minat. Minat tidak dibawa sejak lahir, melainkan diperoleh karena dipengaruhi faktor luar. Hal ini sesuai dengan pendapat Slameto (2010:180) menyatakan bahwa "Minat tidak dibawa sejak lahir, melainkan diperoleh kemudian". Selanjutnya Berndorff (2002:545) bahwa "Interest is considered to be an individual's predisposition to attend to certain stimuli, events, and objects".

\section{METODOLOGI PENELITIAN}

Sampel adalah sebagian dari populasi yang dipandang dapat mewakili seluruh populasi yang ada dalam penelitian. Menurut Arikunto (2006:134): "Untuk sekedar ancer-ancer apabila subjek kurang dari seratus, lebih baik diambil semua sehingga penelitiannya merupakan penelitian populasi...". Melihat jumlah subjek penelitian yang ada kurang dari 100 orang, maka peneliti akan menggunakan seluruh populasi untuk dijadikan sampel dalam penelitian ini yaitu siswa Kelas XI IPS MAN I Medan T.A 2011/2012, sebanyak 80 siswa.

Variabel penelitian ini terdiri dari 2 jenis yaitu:

- Variabel bebas (X) yaitu persepsi siswa tentang ekonomi syariah

- Variabel terikat (Y) yaitu minat mempelajari ekonomi syariah

\section{Uji Instrumen Penelitian}

Untuk mengetahui Validitas dan reliabilitas angket, maka dilakukan uji instrumen pengambilan data. Adapun uji instrumen yang dilakukan adalah :

\section{a. Uji Validitas}

Validitas adalah suatu ukuran menunjukkan tingkat kevalidan atau keaslian instrument. Sebuah instrumen dikatakan valid apabila mampu mengukur apa yang diinginkan. Suatu instrumen dikatakan valid jika $r_{\text {hitung }}>r_{\text {tabel. }}$ Untuk menentukan koefisien validitas angket digunakan Korelasi Product Moment yaitu dengan rumus : 
$r_{X Y}=\frac{N \sum X Y-\left(\sum X\right)\left(\sum Y\right)}{\sqrt{\left\{N \sum X^{2}-\left(\sum X\right) 2\right\}\left\{N \sum Y^{\left.2-\left(\sum Y\right) 2\right\}}\right.}}$

(Arikunto, 2006: 170)

Dimana:

$r_{\mathrm{xy}}=$ Koefisien korelasi antara variabel $\mathrm{X}$ dan variabel $\mathrm{Y}$

$\mathrm{X}=$ skor butir soal yang dihitung validitasnya

$\mathrm{Y}=$ skor total butir soal

$N \quad=$ jumlah sampel

Untuk menafsirkan keberartian harga validitas tiap soal maka harga tersebut dibandingkan dengan harga kritik $r$ product moment dengan ktiteria $r_{\text {hitung }}>r_{\text {tabel }}$ untuk taraf $\alpha=0,05$ maka korelasi product moment tersebut valid, tetapi jika $\mathrm{r}_{\text {hitung }}<\mathrm{r}_{\text {tabel }}$ maka hasil tersebut dinyatakan tidak valid.

\section{b. Uji Reliabilitas}

Untuk menguji reliabilitas digunakan rumus Alpha sebagai berikut :

$$
\mathbf{r}_{11}=\left[\frac{k}{k-1}\right]-\left[1-\frac{\sum \sigma_{b}^{2}}{\sigma_{1}^{2}}\right]
$$

Dimana :

$\mathrm{r}_{11} \quad$ : Reliabilitas yang dicari

$\sum \sigma_{b}^{2} \quad$ : Jumlah Varians skor tiap - tiap item

$\sigma_{1}^{2} \quad$ : Varians total

$\mathrm{K}$ : Jumlah Butir Angket

Untuk mengukur harga reliabilitas soal angket, maka harga tersebut dikonfirmasikan dengan tabel harga kritik $\mathrm{r}$ product moment. Dengan kriteria jika $\mathrm{r}_{\text {hitung }}$ $>r_{\text {tabel }}$ maka soal angket secara keseluruhan tergolong reliabel.

\section{A. HASIL PENELITIAN}

Sebelum angket disebarkan kepada sampel penelitian, maka instrumen angket terlebih dahulu diuji cobakan kepada siswa yang bukan merupakan sampel penelitian dengan jumlah responden 50 orang. Angket diuji validitas dan realibilitasnya melalui Statistical Package for the Social Science (SPSS).

Angket di ujicoba validitasnya dengan menggunakan rumus product moment. Setelah di ujicobakan, maka diperoleh item-item pertanyaan valid dan tidak valid.

Hasil pengujian validitas instrumen angket secara ringkas disajikan pada Tabel 3, sebagai berikut :

Tabel 1

Ringkasan Pengujian Validitas Angket

\begin{tabular}{|l|c|c|c|c|}
\hline \multirow{2}{*}{} & \multicolumn{2}{|c|}{ Item Pertanyaan } & Jumlah & $\begin{array}{c}\text { Nomor Item } \\
\text { Tidak Valid }\end{array}$ \\
\cline { 2 - 5 } & Valid & Tidak valid & 20 & 6 \\
\hline $\begin{array}{l}\text { Persepsi siswa tentang } \\
\text { ekonomi syariah }\end{array}$ & 19 & 1 & 20 & 9 \\
\hline $\begin{array}{l}\text { Minat mempelajari } \\
\text { ekonomi syariah }\end{array}$ & 19 & 1 & & \\
\hline
\end{tabular}


Setelah dilakukan uji validitas angket, selanjutnya dilakukan ujicoba reliabilitas. Ujicoba ini menunjukkan kedua angket yang dipakai cukup dapat dipercaya untuk digunakan sebagai alat pengumpul data atau tidak. Untuk mengukur reliabilitas angket tersebut digunakan rumus $\alpha$, dan hasil pengujian diperoleh hasil sebagai berikut :

Tabel 2

Reliability statistic

\begin{tabular}{|l|r|r|}
\hline & Cronbach's Alpha & \multicolumn{1}{|c|}{ N of Item } \\
\hline $\begin{array}{l}\text { Persepsi siswa tentang } \\
\text { ekonomi syariah }\end{array}$ & .773 & 20 \\
\hline $\begin{array}{l}\text { Minat mempelajari } \\
\text { ekonomi syariah }\end{array}$ & .891 & 20 \\
\hline
\end{tabular}

Teknik analisa data dalam penelitian ini adalah analisis korelasi r produk moment. Hal ini dilakukan sesuai dengan judul penelitian dan identifikasi variabel-variabelnya dimana $\mathrm{r}$ produk moment untuk analisis hubungan atau korelasi antara satu variabel bebas dengan satu variabel terikat. Data yang dideskripsikan pada penelitian ini meliputi data tentang dua variabel yaitu variabel persepsi siswa tentang ekonomi syariah (X), dan variabel minat mempelajari ekonomi syariah (Y).

Secara ringkas data persepsi siswa tentang ekonomi syariah dan minat mempelajari ekonomi syariah dapat dilihat dalam tabel berikut ini.

Tabel 3

Ringkasan Deskripsi Statistik Dasar

\begin{tabular}{|ll|l|l|}
\hline \multicolumn{1}{|c|}{} & \multicolumn{1}{|c|}{ PSE } & \multicolumn{1}{|c|}{ MBS } \\
\hline N & Valid & 80 & 80 \\
& Missing & 0 & 0 \\
Mean & & 64.5000 & 63.6125 \\
Median & 65.0000 & 63.0000 \\
Mode & 66.00 & 63.00 \\
Std. Deviation & & 2.66719 & 2.65527 \\
Variance & & 7.114 & 7.050 \\
Skewness & & -.150 & .639 \\
Std. Error of Skewness & .269 & .269 \\
Minimum & & 57.00 & 58.00 \\
Maximum & & 71.00 & 71.00 \\
Sum & & 5160.00 & 5089.00 \\
Percentiles & 25 & 63.0000 & 62.0000 \\
& 50 & 65.0000 & 63.0000 \\
& 75 & 66.0000 & 65.0000 \\
\hline
\end{tabular}

Keterangan :

PSE : Persepsi Siswa Tentang Ekonomi Syariah

MBS: Minat Mempelajari Ekonomi Syariah 
Berdasarkan tabel 3, diiperoleh rata-rata persepsi siswa tentang ekonomi syariah sebesar 64,50 dengan penyimpangan atau standar deviasi sebesar 2,66719. Selanjutnya untuk minat mempelajari ekonomi syariah diperoleh rata-rata sebesar 63,61 dengan penyimpangan atau standar deviasi sebesar 2,65527.

\section{Tabel 4}

Kategori Persepsi Siswa Tentang Ekonomi Syariah

\begin{tabular}{|l|c|c|c|c|}
\hline & Frequency & Percent & $\begin{array}{c}\text { Valid } \\
\text { Percent }\end{array}$ & $\begin{array}{c}\text { Cumulatif } \\
\text { Percent }\end{array}$ \\
\hline Di bawah rata-rata (kurang baik) & 11 & 13.9 & 13.9 & 13.8 \\
Rata-rata (Baik) & 52 & 65.1 & 65.1 & 78.8 \\
Di atas rata-rata (Sangat baik) & 17 & 21.0 & 21.0 & 100.0 \\
\hline \multicolumn{1}{|c|}{ Total } & 80 & 100.0 & 100.0 & \\
\hline
\end{tabular}

Berdasarkan tabel di atas, dapat dilihat bahwa persentase tertinggi pada kategori rata-rata, dan persentase terendah adalah pada kategori di atas rata-rata. Dari persentase di atas, menunjukkan bahwa mayoritas persepsi siswa tentang ekonomi syariah berada pada kelompok rata-rata (baik) dengan persentase diperoleh sebanyak $65.1 \%$. Selanjutnya, di bawah rata-rata (kurang baik) diperoleh persentase sebanyak $13.9 \%$ dan terakhir di atas rata-rata (sangat baik) diperoleh persentase sebanyak $21.0 \%$.

\section{Deskripsi Variabel Y (Minat Mempelajari Ekonomi Syariah)}

Kategori data minat mempelajari ekonomi syariah dapat diuraikan dalam bentuk tabel dengan ketentuan yaitu :

Tabel 5

Kategori data Minat Mempelajari Ekonomi Syariah

\begin{tabular}{|c|l|}
\hline Skor & \multicolumn{1}{|c|}{ Kategori } \\
\hline $71-67$ & Sangat baik (Sangat Baik) \\
\hline $66-62$ & Baik (Rata-rata) \\
\hline $61-57$ & Kurang Baik (Di bawah rata-rata ) \\
\hline
\end{tabular}

Tabel 6

Kategori Minat Mempelajari Ekonomi Syariah

\begin{tabular}{|l|c|c|c|c|}
\hline & Frequency & Percent & $\begin{array}{c}\text { Valid } \\
\text { Percent }\end{array}$ & $\begin{array}{c}\text { Cumulatif } \\
\text { Percent }\end{array}$ \\
\hline Di bawah rata-rata (kurang baik) & 6 & 7.5 & 7.5 & 7.5 \\
Rata-rata (Baik) & 63 & 78.5 & 78.5 & 86.3 \\
Di atas rata-rata (Sangat baik) & 11 & 14.0 & 14.0 & 100.0 \\
\hline \multicolumn{1}{|c|}{ Total } & 80 & 100.0 & 100.0 & \\
\hline
\end{tabular}

Berdasarkan Tabel di atas, dapat dilihat bahwa persentase tertinggi pada kategori rata-rata, dan persentase terendah adalah pada kategori di atas rata-rata. Dari persentase di atas, menunjukkan bahwa mayoritas minat mempelajari ekonomi syariah berada pada kelompok rata-rata (baik) dengan persentase diperoleh sebanyak 78.5\%. Selanjutnya, di bawah rata-rata (kurang baik) diperoleh persentase sebanyak $7.5 \%$ dan terakhir di atas rata-rata (sangat baik) diperoleh persentase sebanyak $14.0 \%$. 


\section{Analisis Data Penelitian}

Untuk mengetahui korelasi antara persepsi siswa tentang ekonomi syariah (variabel X) terhadap minat mempelajari ekonomi syariah (variabel Y) digunakan rumus product moment. Secara ringkas disajikan pada tabel dibawah ini :

Tabel 7

Korelasi

\begin{tabular}{|rl|r|r|}
\hline & & PSE & \multicolumn{1}{|c|}{ MBS } \\
\hline PSE & Pearson & 1 & $.231^{*}$ \\
& Correlation & & \\
& $\mathrm{N}$ & 80 & 80 \\
\hline MBS & Pearson & $.231^{*}$ & 1 \\
& Correlation & & \\
& $\mathrm{N}$ & 80 & 80 \\
\hline
\end{tabular}

Dari Tabel diperoleh harga $r$ hitung $=0,231$ atau $-1<0,231<1$. Selanjutnya jika dibandingkan dengan $r$ tabel untuk $\mathrm{n}=80$ pada taraf signifikan $95 \%$ atau alpha $=0,05$ didapat $r_{\text {hitung }}>r_{\text {tabel }}$ yaitu 0,231 >0,220 yang sekaligus berarti bahwa ada korelasi antara persepsi siswa tentang ekonomi syariah dengan minat mempelajari ekonomi syariah pada taraf signifikan $95 \%$.

Selanjutnya untuk melihat signifikan tersebut dilakukan uji t. hasil perhitungan disajikan pada tabel dibawah ini:

Tabel 8

Koefisien

\begin{tabular}{|c|c|c|c|c|c|}
\hline \multirow[b]{2}{*}{ Model } & \multicolumn{2}{|c|}{$\begin{array}{l}\text { Unstandardized } \\
\text { Coefficients }\end{array}$} & $\begin{array}{l}\text { Standardized } \\
\text { Coefficients }\end{array}$ & & \\
\hline & B & Std. Error & Beta & $\mathrm{t}$ & Sig. \\
\hline $1 \quad$ (Constant) & 78.475 & 7.079 & & 11.085 & .000 \\
\hline PSE & .230 & .110 & .231 & 2.101 & .039 \\
\hline
\end{tabular}

Berdasarkan Tabel 8 di atas, dapat ditarik kesimpulan bahwa ada korelasi yang positif (signifikan) antara persepsi siswa tentang ekonomi syariah dengan minat mempelajari ekonomi syariah dengan harga $t$ hitung $=2,101$ dan tingkat signifikan 0,039 . Selanjutnya pada taraf signifikan $95 \%$ atau $\alpha=0,05 \mathrm{dan} d \mathrm{k}=\mathrm{n}-2=78$, diperoleh $\mathrm{t}_{\text {tabel }}$ $=1,66$. Dengan membandingkan kedua harga tersebut diperoleh $\mathrm{t}_{\text {hitung }}>\mathrm{t}$ tabel yaitu $2,101>1,66$.

Tabel 9

Model Summary ${ }^{b}$

\begin{tabular}{|l|r|r|r|r|}
\hline Model & R & R Square & $\begin{array}{c}\text { Adjusted R } \\
\text { Square }\end{array}$ & $\begin{array}{c}\text { Std. Error of } \\
\text { the Estimate }\end{array}$ \\
\hline 1 & $.231^{\mathrm{a}}$ & .054 & .041 & 2.59967 \\
\hline
\end{tabular}


Tabel 9 diperoleh dari R Square sebesar 0,054. Angka R Square merupakan pengkuadratan dari koefisien korelasi $\left(0,231^{2}=0,054\right)$. R Square disebut juga koefisien determinasi, yang dalam hal ini berarti bahwa minat mempelajari ekonomi syariah 5,4\% dipengaruhi oleh persepsi siswa tentang ekonomi syariah dan sekaligus berarti bahwa 94,6\% minat mempelajari ekonomi syariah dipengaruhi oleh faktor lain.

\section{Pembahasan Hasil Penelitian}

Setelah terkumpul dan dianalisis, hasil penelitian yang diperoleh menggambarkan bahwa ada korelasi yang positif (signifikan) antara persepsi siswa tentang ekonomi syariah dengan minat mempelajari ekonomi syariah siswa kelas XI MAN I Medan T.A 2011/2012. Hal ini dibuktikan dari hasil pengujian hipotesis pada taraf signifikan $95 \%$ atau $\alpha=0.05$ yaitu diperoleh $\mathrm{t}_{\text {hitung }}>\mathrm{t}_{\text {tabel }}$ yaitu 2,101 $>1,66$.

Hasil penelitian yang dilakukan di MAN I Medan T.A 2011/2012 menunjukkan adanya persepsi yang positif dari siswa tentang ekonomi syariah. Berdasarkan hasil pengujian hipotesis penelitian dan teori yang ada terbukti bahwa ada korelasi yang positif (signifikan) antara persepsi siswa tentang ekonomi syariah dengan minat mempelajari ekonomi syariah, yang sekaligus memberikan makna bahwa semakin baik persepsi siswa tentang ekonomi syariah maka semakin baik pula minat siswa untuk mempelajari ekonomi syariah.

Hasil penelitian diperoleh $\mathrm{r}$ sebesar 0,231 dengan $\mathrm{R}$ square 0,054 (5,4\%). Berdasarkan kategori diperoleh bahwa mayoritas persepsi siswa tentang ekonomi syariah berada pada kelompok rata-rata dengan persentase sebanyak $65,1 \%$, serta ratarata skor 64,5 dan standar deviasi 2,667. Untuk minat mempelajari ekonomi syariah siswa juga diperoleh bahwa berada pada kategori rata-rata 78,5\% dengan rata-rata skor sebesar 63,6 dan standar deviasi 2,655.

Jika siswa mempunyai persepsi yang positif atau menyenangi pelajaran ekonomi syariah maka siswa tersebut akan menunjukkan perilaku yang baik dalam belajar, dan siswa akan menunjukkan minat dan aktivitas belajar yang tinggi. Sebaliknya jika siswa memiliki persepsi yang negatif atau tidak senang terhadap ekonomi syariah maka siswa tersebut akan menunjukkan minat dan perilaku yang kurang baik untuk mempelajari ekonomi syariah.

Penelitian ini sejalan dengan penelitian yang dilakukan Siti Kalimah (2006) mengenai pengaruh motivasi mengajar terhadap persepsi guru mengenai implementasi muatan lokal ekonomi syariah di SMP Tasikmalaya. Berdasarkan penelitian yang dilakukan maka diketahui koefisien korelasi diperoleh $\mathrm{r}=0.392$ dan $\mathrm{R}$ square $=15.4 \%$. Dari hasil analisis regresi diperoleh persamaan regresi yaitu $\mathrm{Y}=41,646+0,609 \mathrm{X}$. Berdasarkan hasil uji $\mathrm{t}$ diketahui $\mathrm{t}_{\text {hitung }}=2,451$, probabilitas $=0,020$ setelah dikonsultasikan dengan $\mathrm{t}_{\text {tabel }}=0,042$ diketahui $\mathrm{t}_{\text {hitung }}>\mathrm{t}_{\text {tabel }}$ maka hipotesis diterima.

\section{A. KESIMPULAN}

Dari hasil penelitian yang telah dilakukan, maka dapat diambil kesimpulan bahwa :

1. Persepsi siswa kelas XI di MAN I Medan T.A 2011/2012 tentang ekonomi syariah, mayoritas tergolong baik yaitu berada pada kelompok rata-rata dengan persentase sebanyak 65,1\%, serta rata-rata skor 64,5 dan standar deviasi 2,667. 
2. Minat mempelajari ekonomi syariah siswa kelas XI di MAN I Medan T.A 2011/2012 mayoritas tergolong baik atau berada pada kategori rata-rata dengan persentase sebanyak 78,5\%, serta rata-rata skor 63,61 dan standar deviasi 2,655.

3. Ada korelasi yang positif dan signifikan antara persepsi siswa tentang ekonomi syariah dengan minat mempelajari ekonomi syariah yang ditunjukkan dari harga koefisien korelasi yaitu $r_{\text {hitung }}=0,231>r_{\text {tabel }}=0,220$

4. Dari hasil perhitungan uji t, untuk mengetahui kontribusi hubungan variabel $X$ dan Variabel $\mathrm{Y}$ diperoleh $\mathrm{t}_{\text {hitung }}=2,101$ dan $\mathrm{t}_{\text {tabel }}=1,66$ pada derajat kebebasan $\mathrm{dk}=\mathrm{n}-2$, dimana $\mathrm{t}_{\text {hitung }}>\mathrm{t}_{\text {tabel }}$ yaitu 2,101 >1,66. Hal ini menunjukkan bahwa hipotesis yang menyatakan bahwa terdapat hubungan yang positif dan signifikan antara persepsi siswa tentang ekonomi syariah dengan minat mempelajari ekonomi syariah siswa kelas XI MAN I Medan T.A 2011/2012, diterima.

\section{DAFTAR PUSTAKA}

Arikunto, S. 2006. Prosedur Penelitian Suatu Pendekatan Praktek. Jakarta: Rineka Cipta.

Berndorff, D. 2002. Journal of Educational Psychology, Interest, Learning, and the Psycological Processes. Vol. 94. No.3. Diakses 21 Mei 2011.

Chaplin, J.P. 2001. Kamus Lengkap Psikologi. Jakarta: Raja Grafindo Persada.

Casdari. 2005. Pengertian Minat Belajar. http://www.infoskripsi.com/2005/ Diakses 15 April 2011.

Echlos, J, and sadly. 2003. Kamus Inggris Indonesia. Jakarta: Gramedia.

Edwin. M. 2009. Journal of International Developmen and Corporation. Islamic Spirit and Morale in Economics. Vol. 15, No. 1-2. Diakses 25 April 2011.

Gani.A.A. 2005.Jurnal ilmu hukum litigasi. Volume 6. No.2. Menggali Akar Landasan Ekonomi Islam. Diakses 25 April 2011.

Gie. 2000. Cara Belajar Yang Baik. Yogyakarta: Gajah Mada.

Gunarsa. 2003. Psikologi Perawatan. Jakarta: Gajah Mada

Jalaluddin, R. 1998. Pengertian Persepsi, http://www.damandiri.or.id/file.pdf. Diakses 10 Maret 2011.

Loekmono. 2003. Menumbuhkan Minat Belajar Siswa. http://www.google.com. Diakses 8 Juni 2011.

Mannan. M. A. 1992. Ekonomi Islam: Teori dan Praktek. Jakarta: Intermasa.

Muttaqin, H. 2004. Jurnal ekonomi ideologis. Meluruskan persepsi Keliru terhadap Ekonomi Syariah. www. Jurnal-ekonomi.org. Diakses 10 Maret 2011.

Nurhidayati. 2006. Hubungan Antara Minat Dengan Prestasi Belajar Siswa Dalam Bidang Studi Sejarah Kebudayaan Islam. Skripsi Pendidikan Agama Islam. Diakses 8 Juni 2011.

Nuruddin, A. 2009. Ekonomi Syariah (menepis badai krisis dalam Semangat kerakyatan ). Bandung : Cita Pustaka Media Perintis.

Pusat Pengkajian dan Pengembangan Ekonomi Islam (P3EI). 2009. Ekonomi Islam. Jakarta: Raja Grafindo Persada.

Purwana, A, E. 2009. Jurnal Al-TAhrir. Vol. 9 No. 2 Juli 2009: 219-244. Bisnis Nabawi : Implementasi bisnis ekonomi islam.

Sanjaya, W. 2006. Strategi Pembelajaran. Jakarta: Kencana.

Sholahuddin. M. 2007. Asas- Asas Ekonomi Islam. Jakarta: Raja Grafindo Persada. 
Siswati. 2003. Hubungan Antara Persepsi Terhadap Pembelajaran Kontekstual Dengan Minat Belajar Matematika Siswa Kelas VII SLTPNegeri 18 Semarang. Skripsi Fakultas Psikologi Diponegoro. Diakses 29 Mei 2011.

Siti Kalimah. 2006. Pengaruh Motivasi Mengajar terhadap Persepsi Guru mengenai Implementasi Muatan Lokal Ekonomi Syariah SMP Tasikmalaya. Semarang. Skripsi Ekonomi. Diakses 29 Mei 2011.

Slameto. 2010. Belajar dan Faktor- Faktor Yang Mempengaruhi. Jakarta: Rineka Cipta. Sudjana. 2002. Metoda Statistika. Bandung: Tarsito.

Sudarsono.J.2007. Pengertian Minat Belajar Siswa, http://one.indoskripsi.com/node/2007. Diakses 15 April 2011

Suhartini. 2001. Ciri-ciri minat mempelajari ekonomi syariah. http://www.infoskripsi.com. Diakses 15 juni 2011.

Syah, M. 2002. Psikologi Belajar. Jakarta: Raja Grafindo Persada.

Tarigan, Akmal. 2006. Dasar-Dasar Ekonomi Islam. Bandung: Cita Pustaka Media.

Wahid. 2000. Menumbuhkan Minat Dan Bakat Anak. Yogyakarta: Pustaka Pelajar.

Syam .2002. Pengertian Persepsi. http://www.google.com/. Diakses 8 Juni 2011

Winkel, W.S. 2004. Psikologi Pengajaran. Jakarta: Gramedia.

Yusrida. 2009. Korelasi Antara Persepsi Siswa Tentang Kegiatan Mengajar Guru Dengan Minat Belajar Ekonomi Siswa Kelas XI SMA Negeri 12 Medan T.A 2008/2009. Medan. Skripsi FE. 